\title{
STAT3 but not ERK2 is a Crucial Mediator against Diet-Induced Obesity via VMH neurons
}

\author{
${ }^{2}$ Gabriel Henrique Marques Gonçalves; ${ }^{1}$ Sabrina Mara Tristão; ${ }^{1}$ Rafaella \\ Eduarda Volpi; ${ }^{1}$ Gislaine Almeida-Pereira; ${ }^{1}$ Beatriz de Carvalho Borges; ${ }^{3}$ José

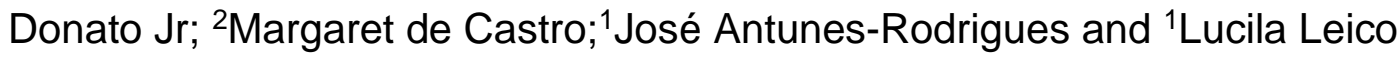 \\ Kagohara Elias.
}

\section{SUPPLEMENTAL DATA}

Figure S1. Validation of mice with deletion of ERK2 in SF1 neurons. (A) Representative images of phosphorylated ERK2 (pERK1/2) in the medio-

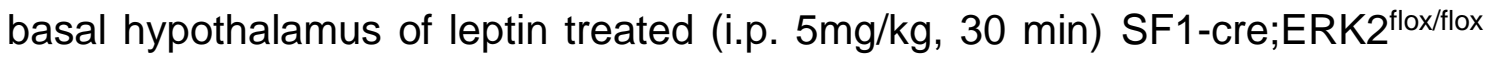
and ERK2 $2^{\text {floxflox }}$ mice ( $n=2$ /group). (B-H) Circadian variation of plasma corticosterone concentrations ( $B ; n=5-6 /$ group), plasma testosterone levels ( $C$; $n=7-12 /$ group), seminal vesicle weight $(D ; n=6-13 /$ group), testis weight $(E ; n=$ 6-13/group), plasma estradiol levels ( $F ; n=4-6 /$ group), uterus weight ( $G ; n=4$ $6 /$ group) and ovaries weight $(H ; n=5-7 /$ group $)$ of SF1-cre;ERK2 $2^{\text {floxfllox }}$ and ERK2 ${ }^{\text {floxflox }}$ mice during estrous at 8-12 weeks of age. Data for $\mathrm{B}-\mathrm{H}$ are shown as means $\pm S D$ and the two-tailed Student $t$ test was used for two-group comparisons

Figure S2. Deletion of ERK2 in SF1 neurons of VMH does not affect energy homeostasis in females under regular diet or HFD. (A-D) Body weight ( $A ; n=7$ /group), cumulative food intake ( $B ; n=7$ /group), serum leptin levels ( $C$; $\mathrm{n}=4-8 /$ group) and $\mathrm{O}_{2}$ consumption (D; $\mathrm{n}=4 /$ group) in SF1-cre;ERK2 $2^{\text {floxfllox }}$ and $E R K 2^{\text {floxflox }}$ female mice on regular diet. (E-G) Body weight ( $E ; n=6-10 /$ group), cumulative food intake ( $F ; n=6-10 /$ group) and serum leptin levels (G; $n=4$ 8/group) in SF1-cre;ERK2 $2^{\text {floxfllox }}$ and ERK2 $2^{\text {floxfllox }}$ female mice on HFD. (H) $\mathrm{O}_{2}$ consumption in body weight paired SF1-cre;ERK2 $2^{\text {floxflox }}$ and ERK2 $2^{\text {floxflox }}$ female mice after 1 week of HFD challenge ( $n=8 /$ group). (I-J) Body weight $(I ; n=$ 6/group) and food intake variation ( $J ; n=6 /$ group) after 5 days of leptin infusion 
(300 ng/h) subcutaneously in SF1-cre;ERK2 $2^{\text {flox/flox }}$ and ERK2 flox/flox male mice. Data for $A, B, E, F$ and $I$ are shown as means \pm SEM and the repeated-measures ANOVA followed by Bonferroni test was used. Data for C, D, G, H and J are shown as means \pm SD and the two-tailed Student $t$ test was used.

Figure S3. Deletion of STAT3 or ERK2 in SF1 neurons of VMH does not affect glucose homeostasis in female mice under regular diet, but lack of STAT3 but not ERK2 is associated with hyperinsulinemia in animals under HFD. (A-C) Glycemia (A; $n=8-13 /$ group), glucose tolerance test $(B ; n=$ 5-7/group) and serum insulin levels (C; $n=8-15 /$ group) in SF1-cre;STAT3 floxfllox and STAT3 ${ }^{\text {floxfflox }}$ female mice on regular diet. (D-E) Glycemia (D; $n=7-8 /$ group) and serum insulin levels (E; $n=6-8 /$ group) in SF1-cre;STAT3 $3^{\text {floxfllox }}$ and STAT3 ${ }^{\text {floxfllox }}$ female mice on HFD diet. ( $\left.F-H\right)$ Glycemia ( $F ; n=7 /$ group), glucose tolerance test (G; $n=4$ /group) and serum insulin levels ( $H ; n=4$-6/group) in SF1-

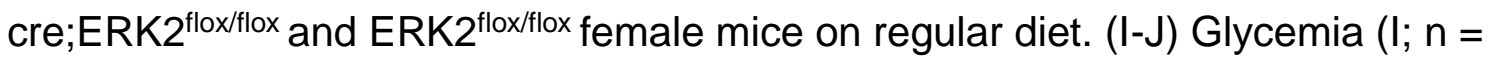
$5-10 /$ group) and serum insulin levels ( $\mathrm{J} ; \mathrm{n}=4-5 /$ group) in SF1-cre;ERK2 floxflox and ERK2 $2^{\text {floxflox }}$ female mice on HFD diet. Data for $B$ and $G$ are shown as means \pm SEM and the repeated-measures ANOVA followed by Bonferroni test was used. Data for $A, C, D, E, F, H, I$ and $J$ are shown as means \pm SD and the two-tailed Student $t$ test was used. ${ }^{*} p<0.05$ versus STAT3 ${ }^{\text {floxfllox }}$ mice. 